either direct or indirect, there will be no appreciable difference in the qualitative result of the radiochemical process. However, the difference in the quantitative result may be of great importance from a biological point of view*. Furthermore, it is elear that the general principles outlined above can also be applied to non-aqueous solutions.

* This was very kindly pointed out to me by Dr. W. M. Dale.

${ }^{1}$ Allsopp, Trans. Faraday Soc., 40, 79 (1944), where a full bibliography will be found.

2 Dale, Meredith, Tweedie, Nature, 151, 280 (1943). Dale, Biochem. $J$, 34, 1367 (1940); 36, 80 (1942); J. Physiol., 102, 50 (1943); Brit. J. Rad., 16, 171 (1943).

${ }^{8}$ Eyring, Hirschfelder and Taylor, J. Chem. Phys., 4, 479 (1936).

4 Risse, Ergebn. Physiologie, 30, 242 (1930).

${ }^{5}$ cf. Fricke, Cold Spring Harbor Sympos., 2, 241 (1934)

${ }^{-}$Arends and Ley, Z. physik. Chem., 6, 240 (1929).

7 Franck and Haber, Sitz. Preuss. Akad. Wiss., 250 (1931).

${ }^{8}$ Franck and Rabinovitch, Trans. Faraday Soc., 29, 120 (1933).

- cf. Weiss, Trans. Faraday Soc., 31, 668 (1935).

${ }^{10}$ Haber and Weiss, Proc. Roy. Soc., A, 147, 332 (1934). Weiss, Trans. Faraday Soc., 31, 1547 (1935).

11 Kailan, Z. physik. Chem., 98, 474 (1921).

12 Lanning and Lind, J. Phys. Chem., 42, 1229 (1938).

${ }^{13}$ Fricke and Hart, J. Chem. Phys., 3, 60 (1935).

14 Clark and Coe, J. Chem. Phys., 5, 97 (1937).

is cf. Weiss, Trans. Faraday Soc., 37, 463 (1941).

\section{FREEDOM FROM WANT OF FOOD}

A PUBLIC conference on "Freedom from Want of Food" was organized by the Watford branch of the Association of Scientific Workers and other local bodies on May 20 to discuss the findings of the United Nations Conference on Food and Agriculture held at Hot Springs, Virginia, last year.

Sir Jack Drummond, of the Ministry of Food, who was one of Great Britain's delegates to Hot Springs, described that meeting as the first conference of the peace. It was concerned with the international planning of the production and distribution of food. Forty-four nations were represented and there were scarcely any conflicting views among the delegates. Scientific men considered how their knowledge of nutrition could be applied to the vast problem of malnutrition; agriculturalists considered how best to produce the vast quantities of food the world requires for the adequate nutrition of all; economists considered how the world's trade could be planned to facilitate the most efficient production and distribution of food. Finally, the findings of these several groups was co-ordinated into the United Nations plan for securing 'Freedom from Want'. By international agreement and planning the nations were to produce and distribute food on the basis of physiological requirements.

The problem, Sir Jack said, is terrifying in its magnitude. For example, in culturally backward countries, better nutrition would result in a vastly better survival-rate of children. Hence populations already numerous would only add to their number and thus aggravate the already terrible problem of adequate food supply. In Britain we have made a start in the rationalization of food distribution. Milk was in short supply in the winter now not because it is being produced in lower quantities than before the War. Actually far more milk is being produced, but it is being allocated to those who need it most -nursing mothers and children. Food-the right kind of food-is now regarded as a very important part of preventive medicine. Medical men are becoming more and more interested in how to prevent disease rather than merely how to cure it. Nutritious food is a great preventative of illness.

Mr. P. Lamartine Yates said that four things are necessary in order that practical results should come out of the deliberations at Hot Springs. First, there must be constant surveys into the state of the nutrition of the people and inquiry into what foods are being eaten. Since the War, the Ministry of Food has made surveys and so has its opposite number in the United States. As a result, a great deal of information on diet and nutrition has become available. These surveys must continue after the War if malnutrition is to be avoided. Secondly, propaganda such as that started by the Ministry of Food to show people what they ought to eat and how they can get the best out of their food should be continuedand extended. Thirdly, there must be a stable relationship between wages and the cost of food. Poverty is the basis of malnutrition and at present food prices are being kept down by means of a Government subsidy of $£ 200$ million a year; this is at $2 s$. a person a week. While Mr. Yates is not in favour of the continuance of such vast subsidies after the War, he thinks that wages and food prices should fluctuate together.

Finally, Mr. Yates urged that someone must be responsible for looking after all this. The United Nations are setting up a permanent international committee in Washington; but on a national scale Mr. Yates believes that a Ministry of Food will still be necessary. We are in for a grim time after the War. Shipping is short and because labour all over the world is engaged in war production there is a world food shortage. Only with difficulty will the United Nations obtain sufficient food to alleviate the worst sufferings of a battered and starving Europe. We must be prepared to put up with rationing of our basic food for a year or two after the War.

There followed a lively discussion and several important points were raised from the floor.

The Conference unanimously adopted a resolution urging that similar conferences should be organized in other parts of Britain to make known to the public the resolutions passed at the Hot Springs Conference. The necessity was accepted for continued rationing of food in Gréat Britain until such time as the population of Europe is ensured of adequate nourishment, and it was resolved that the administration of relief to enemy occupied countries should not be used either directly or indirectly as a means of exerting political pressure upon the populations concerned.

\section{FOOD PRODUCTION IN INDIA}

T $N$ his presidential address to the Section of Agriculture at the thirty-first Indian Science Congress, Ras Bahadur Dr. D. V. Bal presented certain aspects of the present and post-war food production in India.

One of the paramount needs of India at the present time is to lessen the gap between the food produced in the country and the amount required to feed the population adequately. Before the War, home production fell far short of requirements and $2-2 \cdot 6$ million tons were imported annually. The population of India is now much larger than it was a few years ago, but the increase in the area under food crops and normal yields have not been proportionate to the increase in population. The resultant food shortage and occasional famines indicate the urgency of 